Buletin Ilmiah Math. Stat. dan Terapannya (Bimaster)

Volume 08, No. 1 (2019), hal 97 - 102.

\title{
ANALISIS KOINTEGRASI DAN ERROR CORRECTION MODEL INDEKS HARGA KONSUMEN KOTA PONTIANAK DAN SINGKAWANG
}

\author{
Eka Wahyuning Dhewanty, Evy Sulistianingsih, Shantika Martha \\ INTISARI
}

Indeks harga konsumen digunakan sebagai tolak ukur inflasi. Data indeks harga konsumen yang sering kali tidak stasioner menyebabkan pengambilan keputusan yang berkaitan dengan data tidak valid. Uji kointegrasi dipakai untuk menganalisis kemungkinan hubungan jangka panjang antara variabel yang tidak stasioner. Tujuan penelitian ini adalah menemukan hubungan jangka panjang antara indeks harga konsumen kota Pontianak dan kota Singkawang dengan metode kointegrasi dan hubungan jangka pendek dengan metode model koreksi kesalahan. Penelitian ini menggunakan data indeks harga konsumen kota Pontianak dan kota Singkawang dalam periode waktu bulanan. Berdasarkan hasil penelitian yang diperoleh dapat disimpulkan bahwa indeks harga konsumen Kota Pontianak dan Kota Singkawang tidak stasioner tetapi kombinasi linier keduanya stasioner dengan kata lain terdapat hubungan jangka panjang antara indeks harga konsumen kota Singkawang terhadap indeks harga konsumen kota Pontianak.

Kata Kunci : indeks harga konsumen, stasioneritas, kointegrasi.

\section{PENDAHULUAN}

Indonesia sebagai salah satu negara yang sedang berkembang, menempatkan ekonomi sebagai dasar kesejahteraan masyarakatnya. Hal ini dapat dilihat dari indeks harga konsumen yang juga merupakan faktor pendorong atau penghambat kemajuan ekonomi [1]. Data indeks harga konsumen ini merupakan data time series atau runtun waktu [2]. Menurut Badan Pusat Statistik tahun 2017, kota Pontianak dan kota Singkawang, dua kota di provinsi Kalimantan Barat yang diambil sebagai sampel, diyakini cukup mampu menggambarkan kondisi ekonomi di provinsi tersebut.

Seperti yang diketahui, data time series seringkali tidak stasioner sehingga menyebabkan regresi lancung (spurious regression). Regresi lancung adalah situasi dimana hasil regresi menunjukkan koefisien determinasi yang tinggi namun hubungan yang digambarkan oleh koefisien korelasinya tidak saling berhubungan. Error Correction Model atau model koreksi kesalahan adalah sebuah model yang tepat untuk data time series yang tidak stasioner [3].

Tujuan penelitian ini adalah menemukan hubungan jangka panjang antara indeks harga konsumen kota Pontianak dan kota Singkawang dengan metode kointegrasi. Setelah menemukan hubungan jangka panjang, tujuan selanjutnya yaitu menemukan hubungan jangka pendek antara indeks harga konsumen kota Pontianak dan kota Singkawang dengan Error Correction Model.

Langkah awal dalam penelitian ini adalah mengumpulkan data indeks harga konsumen kota Pontianak dan kota Singkawang, kemudian melakukan uji stasioneritas dari data tersebut. Setelah uji stasioneritas memunculkan hasil bahwa kedua data tidak stasioner dalam level namun stasioner pada diferensi pertama, bentuk model hubungan jangka panjang dan uji kestasioneran residual atau variabel gangguan dari model tersebut. Jika variabel gangguan yang digambarkan dengan $\varepsilon_{t}$ dari model jangka panjang tersebut stasioner, maka kedua variabel terkointegrasi. Langkah selanjutnya setelah $\varepsilon_{t}$ stasioner dalam level, maka dilanjutkan dengan menemukan hubungan jangka pendek dengan model koreksi kesalahan. Bentuk model hubungan jangka pendek tersebut dengan menggunakan data awal yang sudah stasioner pada diferensi pertama, kemudian cek koefisien dari kesalahan ketidakseimbangan yang dilambangkan dengan $E C_{t}$ jika signifikan secara statistik, maka model 
koreksi kesalahan yang digunakan valid/sah atau dengan kata lain terdapat penyesuaian model hubungan jangka pendek menuju hubungan jangka panjang.

\section{KOINTEGRASI ENGLE-GRANGER}

Regresi yang menggunakan data time series yang tidak stasioner akan menyebabkan hasil regresi lancung (spurious regression) [3]. Regresi ini terjadi karena koefisien determinasi yang cukup tinggi tetapi hubungan antara variabel dependen dan variabel independennya tidak memiliki makna. Hal ini karena pada kedua variabel yang merupakan data time series hanya menunjukkan trend sehingga koefisien determinasi cukup tinggi, bukan karena hubungan antara kedua variabelnya. Berikut model pada penelitian ini :

$$
Y_{t}=\beta_{0}+\beta_{1} X_{t}+\varepsilon_{t}
$$

Jika data pada variabel dependen dan variabel independen tidak stasioner pada level, namun ada kemungkinan kombinasi linier dari kedua variabel tersebut stasioner. Untuk menunjukkan kemungkinan kombinasi linier kedua variabel stasioner, Persamaan (1) dapat ditulis kembali sebagai berikut [3]:

$$
\varepsilon_{t}=Y_{t}-\beta_{0}-\beta_{1} X_{t}
$$

Dimana kombinasi linier dinyatakan dengan variabel ganguan $\varepsilon_{t}$. Jika $\varepsilon_{t}$ stasioner pada level, maka variabel dependen dan independen dinyatakan terkointegrasi atau memiliki hubungan jangka panjang. Hal ini didukung jika kedua variabel tidak stasioner pada level namun stasioner pada tingkat diferensi yang sama. Pada penelitian ini digunakan uji kointegrasi dari Engle-Granger untuk mengetahui apakah variabel yang diamati terkointegrasi atau tidak .

Uji kointegrasi Engle-Granger ini, dilakukan dengan cara menguji stasioneritas dari residual pada Persamaan (1) dengan metode Dickey Fuller maupun Augmented Dickey Fuller yang memiliki persamaan uji sebagai berikut:

$$
\begin{gathered}
\varepsilon_{t}=\beta_{1} \varepsilon_{t-1} \\
\Delta \varepsilon_{t}=\beta_{1} \varepsilon_{t-1}+\sum_{i=2}^{p} \alpha_{i} \Delta \varepsilon_{t-i+1}
\end{gathered}
$$

Dari hasil estimasi nilai statistik Dickey Fuller maupun Augmented Dickey Fuller pengujian metode ini dibandingkan dengan nilai kritisnya yakni nilai statistik $\tau$ (tau) atau yang lebih dikenal dengan nilai kritis Mackinon (ADF-table) yang ditentukan pada penelitian ini. Jika nilai absolut statistik Augmented Dickey Fuller lebih besar dari nilai kritis $\tau$ Mackinon (ADF-table) yang ditentukan, maka variabel-variabel yang diamati saling berkointegrasi atau memiliki hubungan jangka panjang [3].

\section{ERROR CORRECTION MODEL (ECM) ENGLE-GRANGER}

Jika data time series tidak stasioner pada level namun stasioner di tingkat diferensi yang sama dan terdapat kombinasi linier antara kedua variabel tersebut, maka dapat dikatakan kedua variabel berkointegrasi. Walaupun terdapat hubungan jangka panjang antara kedua variabel, tetapi belum tentu terdapat keseimbangan pada hubungan jangka pendek diantara kedua variabel. Ketidakseimbangan ini berarti bahwa apa yang diinginkan pelaku ekonomi belum tentu sama dengan yang terjadi sebenarnya. Untuk mengatasi ketidakseimbangan ini dibuat model untuk memasukkan penyesuaian untuk melalukan koreksi ketidakseimbangan yang disebut sebagai model koreksi kesalahan (Error Correction Model = ECM).

Model ini pertama kali diperkenalkan oleh Sargan kemudian dikembangkan oleh Hendry hingga akhirnya dipopulerkan oleh Engle-Granger [3]. Kegunaan model ini untuk mengatasi masalah ketidakstasioneran dan regresi lancung pada data time series. Untuk membahas model ini, kita memiliki model hubungan jangka panjang antara variabel $X$ dan $Y$ sebagai berikut:

$$
Y_{t}=\beta_{0}+\beta_{1} X_{t}
$$


Jika $Y_{t}$ memiliki nilai yang berbeda dengan nilai keseimbangannya maka perbedaan sisi kiri dan kanan pada Persamaan (5) sebesar:

$$
E C_{t}=Y_{t}-\beta_{0}-\beta_{1} X_{t}
$$

Nilai perbedaan $E C_{t}$ ini disebut sebagai kesalahan ketidakseimbangan. Jika $E C_{t}$ sama dengan nol, maka $Y$ dan $X$ dalam kondisi seimbang. Karena $Y$ dan $X$ jarang ditemukan dalam kondisi keseimbangan, maka dilakukan observasi hubungan ketidakseimbangan atau hubungan jangka pendek dengan memasukkan unsur kelambanan $Y$ dan $X$. Misalkan dimiliki persamaan sebagai berikut:

$$
\begin{gathered}
Y_{t}=b_{0}+b_{1} X_{t-1}+b_{2} X_{t-1}+\phi Y_{t-1}+\varepsilon_{t} ; 0<\phi<1 \\
\Delta Y_{t}=b_{1} \Delta X_{t}-\lambda\left(Y_{t-1}-\beta_{0}-\beta_{1} X_{t-1}\right)+\varepsilon_{t}
\end{gathered}
$$

Dalam Persamaan (7) tersebut dapat dimasukkan kelambanan tingkat pertama atau juga kelambanan pada tingkat yang lebih tinggi. Pada Persamaan (7) berdampak bahwa nilai $Y$ membutuhkan waktu dalam menyesuaikan secara penuh terhadap variasi $X$. Dari Persamaan (7), terdapat $-\lambda\left(Y_{t-1}-\beta_{0}-\beta_{1} X_{t-1}\right)$ pada Persamaan (8) yang diinterpretasikan sebagai kesalahan keseimbangan dari periode sebelumnya $t-1$ [3].

Persamaan (8) menjelaskan bahwa perubahan $Y$ periode masa sekarang dipengaruhi oleh perubahan $X$ dan kesalahan ketidakseimbangan pada periode sebelumnya. Persamaan (8) merupakan ECM tingkat pertama dengan parameter $\lambda$ adalah parameter penyesuaian, parameter $b$ menjelaskan pengaruh jangka pendek dan parameter $\beta$ menjelaskan pengaruh jangka panjang [3].

ECM yang diturunkan dikenal sebagai model dua langkah dari Engle-Granger. Menurut EngleGranger, jika variabel $X$ dan $Y$ tidak stasioner tetapi terkointegrasi, maka hubungan antar kedua variabel dapat dijelaskan dengan model ECM [3]. Jika dituliskan kembali Persamaan (8) akan menjadi persamaan sebagai berikut :

dimana:

$$
\Delta Y_{t}=\alpha_{0}+\alpha_{1} \Delta X_{t}+\alpha_{2} E C_{t}+\varepsilon_{t}
$$

$E C_{t}=\left(Y_{t-1}-\beta_{0}-\beta_{1} X_{t-1}\right)$

$\alpha_{1}=$ Koefisien jangka pendek

$\alpha_{2}=$ Koefisien koreksi ketidakseimbangan

$\beta_{1}=$ Koefisien jangka panjang

\section{DESKRIPSI DATA}

Penelitian ini mengunakan data sekunder dari Badan Pusat Statistik Provinsi Kalimanta Barat. Data yang digunakan adalah data indeks harga konsumen Kota Pontianak dan Kota Singkawang pada bulan Januari 2010 sampai Desember 2014.

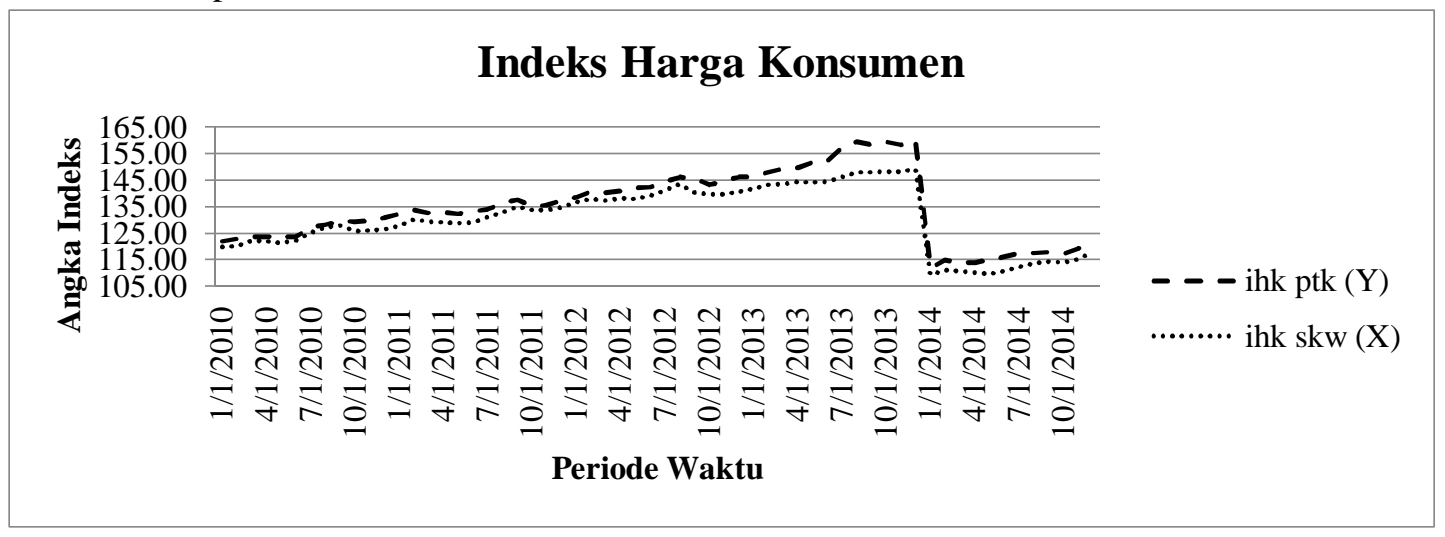

Gambar 1. Data Indeks Harga Konsumen Kota Pontianak Dan Kota Singkawang 
Pada Gambar 1 Terlihat bahwa data IHK Pontianak dan Singkawang mengalami kenaikan tertinggi pada bulan Desember 2013 dan mengalami penurunan pada bulan Januari 2014.

\section{ANALISIS KOINTEGRASI DAN ERROR CORRECTION MODEL INDEKS HARGA KONSUMEN KOTA PONTIANAK DAN KOTA SINGKAWANG}

Langkah-langkah dalam menganalis kointegrasi dan Error Corretion Model indeks harga konsumen kota Pontianak dan kota Singkawang adalah sebagai berikut:

1. Uji Stasioner

Langkah awal dalam penelitian ini adalah menganalisis kestasioneran data IHK Pontianak, IHK Singkawang dan residual dari uji kointegrasi atau residual dari model persamaan jangka panjang. Kestasioneran data IHK dapat dilihat dengan mengunakan uji akar unit ADF dengan pengujian hipotesis sebagai berikut:

Hipotesis :

$H_{0}$ : terdapat unit root atau data tidak stasioner

$H_{1}$ : tidak terdapat unit root atau data stasioner

Dengan pengambilan keputusan jika nilai absolut ADF-test > ADF-table pada 5\%, maka $H_{0}$ ditolak, data stasioner. Sedangkan jika nilai absolut ADF-test $<$ ADF-table pada 5\%, maka $H_{1}$ ditolak, data tidak stasioner. Hasil pengujian kestasioneran masing-masing variabel ditunjukkan sebagai berikut:

Tabel 1. Hasil Uji Stasioneritas Level Metode ADF-Test

\begin{tabular}{ccccc}
\hline Variabel & ADF-test & Prob & ADF-table pada 5\% & Kesimpulan \\
\hline IHK PTK & $-1,807$ & 0,689 & $-3,488$ & Tidak stasioner \\
IHK SKW & $-1,727$ & 0,727 & $-3,488$ & Tidak stasioner \\
\hline
\end{tabular}

Dari hasil pengolahan pada Tabel 1 seluruh variabel tidak stasioner pada tingkat level, hal ini dilihat dari nilai absolut statistik ADF-test IHK Pontianak dan IHK Singkawang yang lebih kecil dibanding nilai ADF-table 5\% sehingga mengambil keputusan untuk menolak $H_{1}$ atau data penelitian tidak stasioner. Dengan kata lain data IHK Pontianak dan IHK Singkawang merupakan data runtun waktu yang tidak stasioner sehingga diperlukan differencing.

Tabel 2. Hasil Uji Stasioneritas First Differencing Metode ADF-Test

\begin{tabular}{ccccc}
\hline Variabel & ADF-test & Prob & ADF-table pada 5\% & Kesimpulan \\
\hline DIHK PTK & $-8,180$ & 0,000 & $-3,489$ & Stasioner \\
DIHK SKW & $-7,901$ & 0,000 & $-3,489$ & Stasioner \\
\hline
\end{tabular}

Pada Tabel 2 hasil uji stasioner diketahui bahwa semua variabel stasioner di first difference . Hal ini dapat dilihat dari nilai absolut ADF-test IHK Pontianak dan IHK Singkawang yang lebih besar dari ADF-table $5 \%$ sehingga mengambil keputusan untuk menolak $H_{0}$ dengan kata lain data stasioner pada first differencing atau data IHK Pontianak dan IHK Singkawang stasioner pada tingkat diferensi pertama.

2. Uji Kointegrasi

Kedua variabel bisa kointegrasi apabila mereka memiliki hubungan jangka panjang. Kointegrasi sendiri memiliki arti walaupun masing-masing variabel tidak stasioner tetapi memiliki kombinasi linier yang stasioner [5]. Model persamaan jangka panjang dibentuk dari variabel-variabel yang tidak stasioner sehingga sering kali disebut regresi lancung. Dari hasil pengolahan data dengan program $E$ views didapat model persamaan jangka panjang sebagai berikut :

$$
\text { IHKPTK }_{t}=-10,345+1,112 I H K S K W_{t}+\varepsilon_{t}
$$

Berikut hasil pengujian dari Persamaan 10.

Tabel 3. Hasil Pengujian IHK Singkawang Terhadap IHK Pontianak 


\begin{tabular}{ccccc}
\hline Variabel & Koefisien & Std. Error & t-statistik & Prob \\
\hline IHKSKW & 1,112 & 0,025 & 44,619 & 0,000 \\
C & $-10,345$ & 3,267 & $-3,166$ & 0,003 \\
\hline
\end{tabular}

Dari hasil pengujian yang ditampilkan pada Tabel 3 diperoleh bahwa IHK Singkawang mempengaruhi IHK Pontianak. Hal ini dapat dilihat dari nilai probabilitas yang lebih kecil dari nilai kritis 5\%. Setelah model persamaan jangka panjang, langkah selanjutnya menguji kestasioneran $\varepsilon_{t}$ untuk mengetahui apakah IHK Singkawang dan IHK Pontianak terkointegrasi.

\begin{tabular}{lccc}
\hline \hline & t-Statistic & Prob. $^{*}$ \\
\hline \hline Augmented Dickey-Fuller test statistic & -1.994617 & 0.0449 \\
\hline Test critical values: & $1 \%$ level & -2.604746 & \\
& $5 \%$ level & -1.946447 & \\
& $10 \%$ level & -1.613238 & \\
\hline \hline
\end{tabular}

*MacKinnon (1996) one-sided p-values.

Gambar 2. Hasil Uji Stasioner Residual Model Persamaan Jangka Panjang

Berdasarkan hasil uji kointegrasi Engle Granger yang dilakukan pada Gambar 2 nilai absolut statistik ADF-test lebih besar dibanding nilai ADF-table pada 5\% maka $\varepsilon_{t}$ stasioner. Jika $\varepsilon_{t}$ stasioner maka terdapat hubungan jangka panjang yang signifikan antara IHK Singkawang terhadap IHK Pontianak (terkointegrasi).

3. Model Koreksi Kesalahan (Error Correction Model)

Syarat untuk melakukan Error Correction Model adalah $\varepsilon_{t}$ harus stasioner atau dengan kata lain kedua variabel terkointegrasi seperti yang ditunjukkan pada Gambar 2 yang menunjukkan $\varepsilon_{t}$ stasioner. Hal yang selanjutnya dilakukan adalah membentuk model persamaan jangka pendek (Error Correction Model) antara IHK Singkawang terhadap IHK Pontianak. Pengujian ini dilakukan dengan menggunakan variabel yang stasioner melalui metode diferensi data. Model persamaan jangka pendek pada penelitian ini sebagai berikut :

$$
\Delta I H K P T K_{t}=0,043+1,184 \Delta I H K S K W_{t}-0,090 E C_{t}+\varepsilon_{t}
$$

Hasil pengujian dari model persamaan jangka pendek antara IHK Singkawang terhadap IHK Pontianak dapat dilihat dari Tabel 4 dibawah ini

Tabel 4. Hasil Pengujian IHK Singkawang Terhadap IHK Pontianak Dengan Menggunakan Hasil Differencing

\begin{tabular}{ccccc}
\hline Variabel & Koefisien & Std. Error & t-statistik & Prob \\
\hline DIHKSKW & 1,184 & 0,028 & 42,609 & 0,000 \\
EC $_{\boldsymbol{t}}$ & $-0,090$ & 0,065 & $-1,382$ & 0,1724 \\
$\mathbf{C}$ & 0,043 & 1,45 & 0,296 & 0,768 \\
\hline
\end{tabular}

Dapat dilihat dari Tabel 4 terdapat beberapa variabel dalam model yang probabilitasnya lebih besar dari nilai kritis 5\%. Dilakukan estimasi ulang model tersebut, dengan cara menghapus variabel yang memiliki nilai probabilitasnya lebih besar dari nilai kritis $5 \%$ yaitu variabel $C$ dan $E C_{t}$ sehingga didapat hasil seperti pada tabel dibawah ini

Tabel 5. Hasil Pengujian IHK Singkawang Terhadap IHK Pontianak Dengan Menggunakan Hasil Differencing Tanpa Variabel C Dan EC

\begin{tabular}{lllll}
\hline Variabel & Koefisien & Std. Error & t-statistik & Prob \\
\hline DIHKSKW & 1,193 & 0,027 & 44,276 & 0,000 \\
\hline
\end{tabular}

Dapat dilihat dari Tabel 3.6 bahwa pada jangka pendek kenaikan IHK Singkawang sebesar 1 satuan akan memiliki pengaruh positif terhadap IHK Pontianak sebesar $1,193 \%$. Hal ini dilihat dari nilai 
probabilitas yang lebih kecil dibanding dengan nilai kritis 5\%. Penyesuaian satu periode model jangka pendek menuju jangka panjang tidak begitu berarti. Hal ini dikarenakan model jangka pendek yang digunakan ini tidak sah/valid. Hal ini dilihat dari probabilitas EC yang lebih besar dibanding nilai kritis 5\% sehingga harus dihilangkan dari model tersebut [4].

\section{KESIMPULAN}

Berdasakan hasil penelitian, diperoleh kesimpulan sebagai berikut:

1. IHK kota Pontianak dan IHK kota Singkawang merupakan data time series yang tidak stasioner namun memiliki kombinasi linier yang stasioner sehingga berkointegrasi atau memiliki hubungan jangka panjang.

2. Terdapat hubungan jangka panjang antara IHK Singkawang terhadap IHK Pontianak dengan model sebagai berikut

$$
\text { IHKPT K } K_{t}=-10,345+1,112 I H K S K W_{t}+\varepsilon_{t}
$$

Pada hubungan jangka panjang jika angka IHK kota Singkawang naik sebesar 1\%, maka akan menyebakan kenaikan angka indeks kota Pontianak sebesar 1,112 \%. Dari model dapat dikatakan IHK Singkawang berpengaruh positif terhadap IHK Pontianak. Model jangka panjang yang digunakan ini sah/valid dan kedua variabel terkointegrasi. Hal ini dilihat $\varepsilon_{t}$ yang stasioner pada nilai kritis 5\%. Dengan kata lain IHK Pontianak dan IHK Singkawang terkointegrasi.

3. Model koreksi kesalahan antara IHK Singkawang terhadap IHK Pontianak digambarkan dengan model sebagai berikut

$$
\Delta I H K P T K_{t}=1,193 \Delta I H K S K W_{t}+\varepsilon_{t}
$$

dimana kenaikan IHK Singkawang sebesar 1 angka indeks akan memiliki pengaruh positif terhadap IHK Pontianak sebesar 1,193\%. Hal ini dilihat dari nilai probabilitas yang lebih kecil dibanding dengan nilai kritis 5\%. Penyesuaian satu periode model jangka pendek menuju jangka panjang tidak begitu berarti. Hal ini dikarenakan model jangka pendek yang digunakan ini tidak sah/valid. Hal ini dilihat dari probabilitas EC yang lebih besar dibanding nilai kritis 5\% sehingga harus dihilangkan dari model tersebut. Hal ini dapat diartikan sebagai IHK Pontianak menyesuaikan perubahan IHK Singkawang pada periode yang sama. Dengan kata lain penyesuaian satu periode model jangka pendek menuju jangka panjang tidak begitu berarti.

\section{DAFTAR PUSTAKA}

[1]. Saputra, Mariani J., Setiawan A., Mahatma, T., Analisis Kointegrasi Data runtun Waktu Indeks Harga Konsumen Beberapa Komoditas Barang Kota di Jawa Tengah. Prosiding Seminar Nasional Penelitian. 2012 Juni:2(12): 177-184

[2]. IHK Kota Pontianak dan Singkawang 2010-2014 [Internet]. 2015. Available from: https://kalbar.bps.go.id/dynamictable/2015/03/20/3/ihk-pontianak-dan-singkawang-2010-2014dinamis-.html.

[3]. Widarjono, Agus. Ekonometrika : Pengantar dan Aplikasinya. Yogyakarta : Ekonisia. 2009.

[4]. Junaidi. Juanda, Bambang. Ekonometrika Deret Waktu : Teori dan Aplikasi. Bogor : IPB Press. 2012

[5]. Gujarati, Damodar, N. Dasar-dasar Ekonometrika. Jakarta. Salemba Empat. 2012

EKA WAHYUNING DHEWANTY : Jurusan Matematika FMPA UNTAN, Pontianak, hunkaitaeminho@gmail.com

EVY SULISTIANINGSIH $\quad$ : Jurusan Matematika FMPA UNTAN, Pontianak, evysulistianingsih@math.untan.ac.id

SHANTIKA MARTHA

: Jurusan Matematika FMPA UNTAN, Pontianak, shantika.martha@math.untan.ac.id 